\title{
Brazilian consumers' perception of edible insects
}

\author{
Igor Sulzbacher Schardong ${ }^{1}$ Joice Aline Freiberg ${ }^{2}$ (D) Natielo Almeida Santana ${ }^{2}$ (I) \\ Neila Silvia Pereira dos Santos Richards ${ }^{3 *}$ iD
}



ABSTRACT: It is estimated that by 2050 the world population will be 9 billion people; and therefore, the need for alternative sources of protein is inevitable, since conventional sources, such as beef, pork and poultry, will not be sufficient to meet the demand of population growth. Food that includes alternative sources of protein, such as insects, is a reality in countries of Latin America, Asia, Australia, Europe and Africa. This research presents the results of an exploratory study that analysed the food profile of 1,619 consumers in the five Brazilian regions (North, Northeast, Midwest, Southeast and South) as well as their perception, motivation and preferred form of edible insects. The data were analysed by cross-tabulation and expressed as frequencies. Our results show that women are more reluctant than men to consume insects. In general, there is a preference for consumption of insects in the form of flour. However, those with more familiarity with this type of consumption prefer the whole insect. Most Brazilian consumers have no opinion about the safety of consuming insects; however, consumers with higher levels of education and familiarity consider it safe.

Key words: entomophagy, food preference, food profile, food safety, neophobia.

Percepção de consumidores brasileiros aos insetos comestíveis

RESUMO: Estima-se que em 2050 a população mundial contará com cerca de 9 bilhões de pessoas, e, portanto, a necessidade de fontes alternativas de proteina é inevitável, uma vez que as fontes convencionais, como carne de gado, suínos e aves, não serão suficientes para suprir a demanda do crescimento populacional. A alimentação que inclui fontes alternativas de proteina, como os insetos, é uma realidade em paises da América Latina, Ásia, Austrália, Europa e Africa. Esta pesquisa apresenta os resultados de um estudo exploratório que analisou o perfil alimentar de 1.619 consumidores das cinco regiōes brasileiras (Norte, Nordeste, Centro-Oeste, Sudeste e Sul) quanto sua percepção, motivação e forma preferencial aos insetos comestiveis. Os dados foram analisados através de frequências cruzadas e expressos em porcentagem. Nossos resultados mostram que mulheres apresentam maior aversão ao consumo de insetos do que homens. Em geral, há preferência em consumir os insetos na forma de farinha, e inteiro para aqueles com mais familiaridade ao consumo de insetos. Majoritariamente, os consumidores brasileiros não tem opinião sobre a segurança em consumir insetos, contudo, em maiores níveis de escolaridade e a familiaridade os consumidores posicionam-se quanto à sua segurança.

Palavras-chave: entomofagia, preferência alimentar, perfil alimentar, segurança alimentar neofobia.

\section{INTRODUCTION}

Insect-based foods have already been adopted in several countries (MASON et al., 2018; ROOS, 2018). According to the Food and Agriculture Organization (FAO, 2013), the consumption of insects should be encouraged for health, ecosystem and subsistence reasons (social and economic factors). There are over 1,900 species of insects with the potential for consumption and a sustainable supply of nutrients (FAO, 2013). Insects stand out in their nutritional properties because they contain all the essential amino acids (BLÁSQUEZ et al., 2012), many polyunsaturated fatty acids (RUMPOLD \& SCHLÜTER, 2013) and a high variety of nutrients such as copper, iron, magnesium, manganese, phosphorus, selenium and zinc, plus vitamins riboflavin, biotin, pantothenic acid and, in some cases, folic acid (NOWAK et al., 2016; RUMPOLD $\&$ SCHLÜTER, 2013). These nutrients are present at levels as significant as those in conventional sources of protein.

Despite the various nutritional benefits, the potential of edible insects is still little explored 
(FAO, 2013). Psychology and intellectual tradition of each individual (HOUSE, 2016), as well as cultural habits and some prejudices, are obstacles to the introduction of this type of food in the diet. In Western countries, for example, foods containing insects are viewed with disgust and scepticism by consumers (VANHONACKER et al., 2013; VERBEKE, 2015), who prefer conventional meals (SCHÖSLER et al., 2012) and choose not to consume them (SCHULP \& BRUNNER, 2018). In contrast, in places such as Africa, Australia, Asia, Venezuela and Colombia, insects make up the diet of society, being consumed mainly by indigenous tribes (CHOO et al., 2009; PAOLETTI et al., 2000).

The acceptance of insects in the diet of consumers has been investigated by many researchers. Questionnaires are frequently used to find ways to demystify the consumption of insects in different countries. In Zimbabwe, although rural population habitually consumes insects, about $80 \%$ of the urban population also consumes them (MANDITSERA et al., 2018). In developed countries, such as Germany, insects are more accepted in food when supplied in a processed form, unlike in China, where both processed and unprocessed forms are accepted by the consumer (HARTMANN et al., 2015). Conversely, in the United States, most North Americans have never consumed insects, have never heard about entomophagy and are still reluctant to use them (WOOLF et al., 2019); however, compared with North Americans, Indians have a greater aversion to insects as food for the reason that ingestion of insects infringes sacred values (RUBY \& ROZIN, 2019). In addition to the consumption of insects, in Latin America, indigenous tribes of Colombia and Brazil use insects in medicine, folklore and mythology; in Mexico, insects are consumed by the Aztec population (DE FOLIART, 2002).

In Latin America, few studies have reported consumer perceptions regarding the consumption of edible insects. In Brazil, CHEUNG \& MORAES (2016) reported that most consumers associate insect consumption with the words 'disgust' and 'no', while 'prefer' is the verb associated with meat consumption. This preference results in high availability of other sources of protein, such as beef, which has an average consumption of $38.6 \mathrm{~kg} /$ inhabitant/year in the country (GOMES et al., 2017).

Anxiety and fear of the unknown and potentially dangerous food causes food neophobia, a factor usually evaluated from questionnaires through questions that identify consumer acceptance of trying something new (PIHA et al., 2018). In Belgium, neophobia explains consumers' aversion to substituting meat for insects (VERBEKE, 2015). Rejection is justified by the preference for innovations where individuals recognize something familiar in the new product (FISCHLER, 1995, 2010). Demystification of insect consumption in regions where neophobia and disgust are present should occur gradually and may begin with public and private discussions on the benefits of products with insects in their composition (LA BARBERA et. al., 2018), education programmes, government support and academic research elucidating the potential and benefits of this source of protein (GAHUKAR, 2016).

In this context, the aims of this study was to know the food profile of consumers in the five Brazilian geographic regions (North, Northeast, Midwest, Southeast and South), the acceptance of insects in the diet, the preferred form of ingestion, and the opinion of the consumers regarding the safety of eating edible insects.

\section{MATERIALS AND METHODS}

This study was developed through exploratory, descriptive research, with a quantitative approach. The research strategy was to verify the results through objectives previously defined. The survey covered the five Brazilian geographic regions: North, Northeast, Midwest, Southeast and South, where 1,619 people participated effectively.

In 2010, the Brazil population was $190,755,799$, with $84 \%$ of habitants living in cities. The Southeast region $(80,364,410$ habitants) has the highest population concentration, followed by the Northeast $(53,081,950)$, South $(27,386,891)$, North $(15,864,454)$ and Midwest $(14,058,094)$. For the genders, $48.97 \%$ are men and $51.03 \%$ of the population are women, with a higher percentage of men in relation to women only in the Northeast region. Regarding age, $65.5 \%$ of population in 2010 was between 15 and 64 years old, $24.0 \%$ between 0 and 14 years old, and $7.3 \% 65$ or more years old (IBGE, 2010). For school level, $30.7 \%$ of the population over the age of 25 years old have 11 to 14 years of study, and only $9.5 \%$ have 1 to 3 years of study (IBGE, 2015). Currently, the Brazilian population is estimated at more than 209 million inhabitants (IBGE, 2019). Regarding the consumption of meat by Brazilian population, in 2015 was consumed 38.6, 15.9 and $43 \mathrm{~kg} /$ habitant/year of beef, pork and poultry (ABPA, 2019). In addition, a small portion of the population $(<30 \%)$ consumes other alternative protein sources, such as soybean protein, once per month (BEHRENS \& SILVA, 2004; GÓMEZ-LUCIANO et al., 2019). 
The survey was performed through a questionnaire formulated in Google Drive (see questionnaire in Supplementary Material); it was disseminated on social networks (Facebook ${ }^{\circledR}$, WhatsApp ${ }^{\circledR}$, Google Plus ${ }^{\circledR}$, LinkedIn $\left.{ }^{\circledR}\right)$ and via email to the general population. Access to the questionnaire was possible after agreement with the Free and Informed Consent Term, where personal image protection, voluntariness, anonymity guarantee, the right to refuse to participate in the research, and withdrawal of consent were established at any time, without damage or loss (BRASIL, 2012).

The questionnaire contained 11 open and closed questions, which included: name, city and state of birth, gender, sexual orientation, age, schooling level, eating habits (eats everything, lactovegetarian, ovo-lactovegetarian, vegetarian and vegan); sporadic consumption of insects (at any time and on what occasion); preference in the consumption of insects (in the form of flour which cannot be seen on the plate; whole roast/fried/cooked; in pieces; as an ingredient in cakes and pies which the insect is added such as a part of recipes; or other forms); why they consume insects and their opinion about safety when eating them (unsafe, safe, extremely unsafe, extremely safe, very unsafe, very safe and no opinion). The participants were grouped into five groups according to age: 0 to 20,21 to 30,31 to 40 , 40 to 50 and above 50 years of age.

Data collection was carried out from January to June 2018. The database obtained on Google Drive was analysed through cross-tabulation, and results expressed as frequencies. A chi-squared test was performed to determine association and significance between the variables. According to the assumptions of the test, we combined sub-groups of variables with a lower number of observations. In this way, we performed the analysis for three regions (South, Southeast and Midwest + North + Northeast); three opinions about safety (insecure + very insecure + extremely insecure, safe + very safe + extremely safe, and no opinion); two preferred forms of consumption (eat everything and lactovegetarian + ovo-lactovegetarian + vegan + vegetarian); and three levels of education (middle school + high school, undergraduate, and postgraduate + postdoctoral). All analysis was performed using Statistical Analysis System (SAS) version 9.1.

\section{RESULTS}

\section{Sociodemographic profile of the participants}

The respondents were mostly female $(62.45 \%)$, aged between 21 and 30 years old $(47.50 \%)$ and had access to higher education (63.19\%) (Table 1). In all the states, there was a predominance of female respondents, and the largest number of responses was in the states of the South and Southeast.

Regarding sexual orientation, $80.67 \%$ of the participants are heterosexual. Forty-seven men $(2.90 \%)$ and 29 women (1.79\%) claimed to be homosexual; 492 (30.39\%) men and 814 (50.28\%) women claimed to be heterosexual, and 105 women (6.49\%) and 25 men (1.54\%) claimed to be bisexual.

Regarding food habits, $92.81 \%$ presented a very varied diet, followed by ovo-lactovegetarians (3.28\%). Regarding gender, 911 (56.44\%) women and $587(36.37 \%)$ men affirmed that they eat everything; 43 women $(2.66 \%)$ and $10(0.62 \%)$ men claimed to

Table 1 - Sociodemographic data of Brazilian consumers.

\begin{tabular}{|c|c|c|}
\hline Sociodemographic data & $\mathrm{n}$ & $\%$ \\
\hline \multicolumn{3}{|c|}{-----------------------------------Gender-------------------------------- } \\
\hline Male & 608 & 37.55 \\
\hline Female & 1011 & 62.45 \\
\hline \multicolumn{3}{|c|}{-------------------------------------'Age----------------------------------' } \\
\hline Up to 20 & 472 & 29.19 \\
\hline 21 to 30 & 768 & 47.50 \\
\hline 31 to 40 & 177 & 10.95 \\
\hline 41 to 50 & 100 & 6.18 \\
\hline More than 50 & 100 & 6.18 \\
\hline \multicolumn{3}{|c|}{ 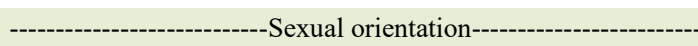 } \\
\hline Asexual & 1 & 0.06 \\
\hline Bisexual & 130 & 8.03 \\
\hline Heterosexual & 1306 & 80.67 \\
\hline Homosexual & 76 & 4.69 \\
\hline Did not answer & 106 & 6.55 \\
\hline \multicolumn{3}{|c|}{-------------------------Levels of education------------------------ } \\
\hline Middle school & 28 & 1.73 \\
\hline High school & 242 & 14.95 \\
\hline Undergraduate & 1023 & 63.19 \\
\hline Postgraduate & 296 & 18.28 \\
\hline Postdoctoral & 30 & 1.85 \\
\hline \multicolumn{3}{|c|}{ 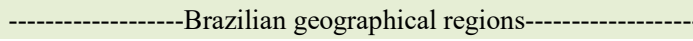 } \\
\hline North & 42 & 2.59 \\
\hline Northeast & 62 & 3.83 \\
\hline Midwest & 55 & 3.40 \\
\hline Southeast & 365 & 22.54 \\
\hline South & 1095 & 67.63 \\
\hline \multicolumn{3}{|c|}{ 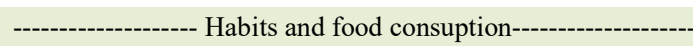 } \\
\hline I eat everything & 1498 & 92.81 \\
\hline Lactovegetarian & 5 & 0.31 \\
\hline Ovo-lactovegetarian & 53 & 3.28 \\
\hline Vegan & 17 & 1.05 \\
\hline Vegetarian & 41 & 2.54 \\
\hline
\end{tabular}

Ciência Rural, v.49, n.10, 2019. 
be ovo-lactovegetarians; $36(2.23 \%)$ women and five $(0.31 \%)$ men are vegetarians, and 14 men $(0.87 \%)$ and three women $(0.19 \%)$ are vegans.

\section{Consumption of insects}

We observed an association between consumption and region $\left[\chi^{2}(3)=24.57, p<0.0001\right]$. Of the total number of respondents, $85.79 \%$ never consume insects. The North region had the highest insect consumption $(21.43 \%)$, and the South region had the lowest $(11.23 \%)$ (Figure 1A). Regarding safety in the consumption of insects, 739 (45.67\%) respondents claimed no opinion and 338 (20.89\%) believe it to be safe. In addition, $50.44 \%$ of the participants who have already consumed insects believe that this source is safe, very safe or extremely safe, followed by $33.91 \%$ who have no opinion, and only $15.65 \%$ who claimed it to be unsafe, very unsafe or extremely unsafe. Among the participants who do not consume insects, $47.62 \%$ have no opinion, followed by $30.25 \%$ who claimed it to be unsafe, very unsafe or extremely unsafe (Figure $1 \mathrm{~B})\left[\chi^{2}(6)\right.$ $=8.06, \mathrm{p}=0.23]$. A significant association between consumption and preferred form of consumption was observed $\left[\chi^{2}(4)=14.70, p=0.0054\right]$. Of the total participants, $85.78 \%$ who have not consumed insects would rather eat them in the form of flour $(61.96 \%)$, followed by whole $(14.91 \%)$ and as an ingredient (12.03\%). Out of the 230 that have already consumed insects, $54.34 \%$ prefer the form of flour and $23.91 \%$ the whole insect (Figure 1C). Despite the relationship between habit and food consumption, no significant association was reported $\left[\chi^{2}(1)=3.66, p=0.0556\right]$ (Figure 1D).



Ciência Rural, v.49, n.10, 2019. 


\section{Preferred form of insect consumption}

The preferred form of consuming insects was significantly associated with region $\left[\chi^{2}(12)\right.$ $=36.18, \mathrm{p}=0.0003]$. In general, participants from different regions, with a different level of education, age and gender preferred to consume insects in the form of flour (60.9\%), which cannot see on the plate, following by whole $(16.2 \%)$ and as an ingredient $(11.5 \%)$ of cakes or pies whose insect is added whole or in the form of pieces in recipes (Figure 2). Regarding the regions, those in the Midwest (14.55\% of respondents from this region) and Southeast $(13.42 \%)$ would also appreciate insects as an ingredient, while those in the Northeast (17.74\%) and South (19.38\%) would appreciate the whole form; and those in the North $(11.9 \%)$ would appreciate other forms of consumption (Figure 2A). The preferred form of consumption did not present significant association with level of education $\left[\chi^{2}\right.$ $(8)=15.11, p=0.0571]$ or age $\left[\chi^{2}(16)=15.07, p=\right.$ $0.5192]$ (Figure 2B and 2C).
Regarding gender, we also observed an association with consumption $\left[\chi^{2}(4)=61.09\right.$, p < $0.0001]$, where $62.47 \%$ of women and $58.23 \%$ of men prefer the form of flour. In addition, $23.85 \%$ of men prefer to eat whole insects, while $14.16 \%$ of women choose to consume them as an ingredient (Figure 2D).

\section{Safety in insect consumption}

The opinion about safety in eating insects showed an association with preference $\left[\chi^{2}(8)=35.40\right.$, $\mathrm{p}<0.0001]$ and level of education $\left[\chi^{2}(4)=24.15\right.$, $\mathrm{p}<0.0001]$. There was a preference for the whole and pieces forms for those to whom the consumption of insects is safe, very safe and extremely safe. Conversely, flour and other forms were preferences for those who claimed that the consumption is unsafe, very unsafe or extremely unsafe (Figure 3A). Regarding regions, no association with preferred form was reported $\left[\chi^{2}(6)=8.0559, \mathrm{p}=0.2341\right]$; however, in the different regions, the perception that insect

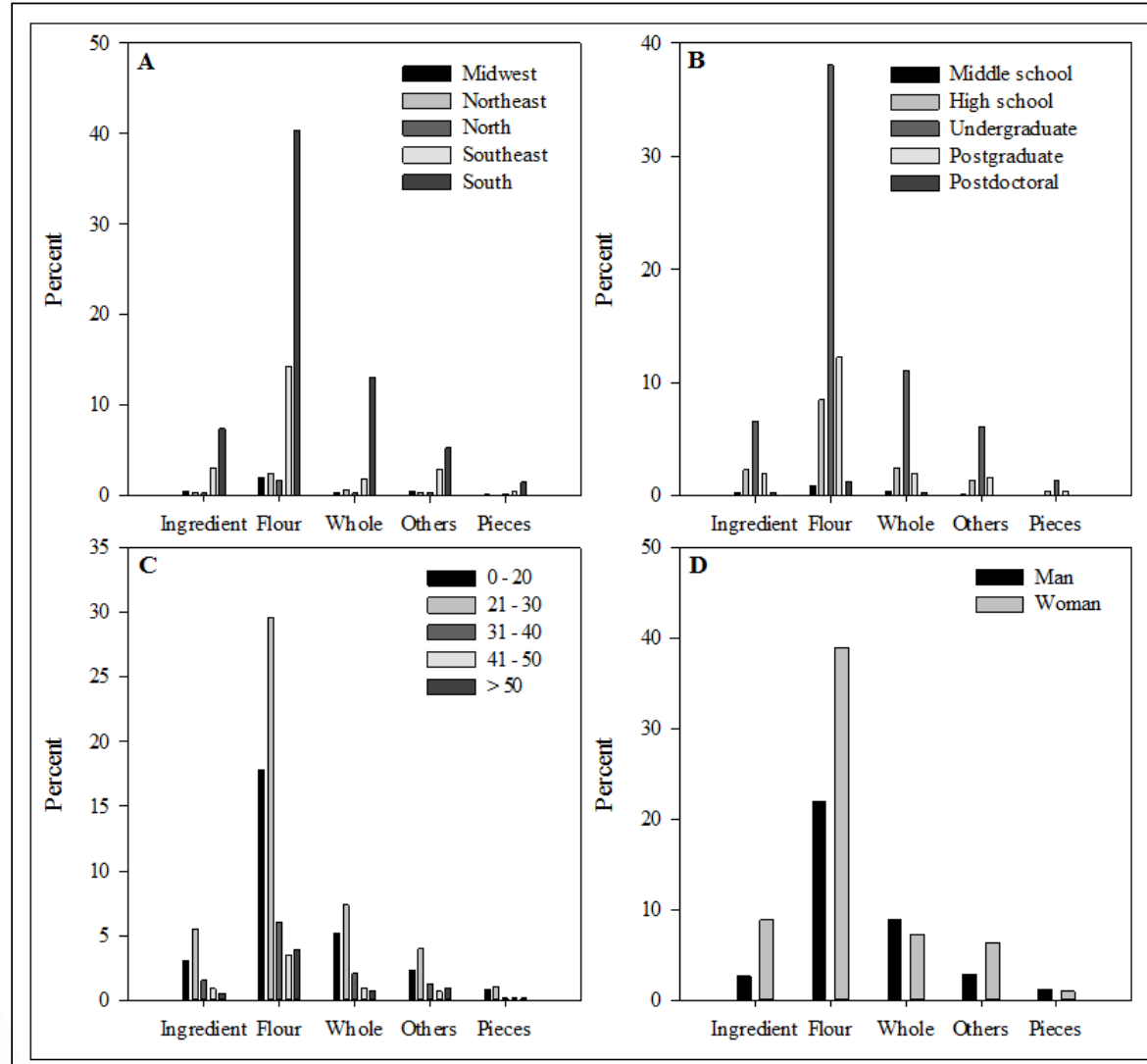

Figure 2 - Frequency (\%) of the preferred form of consumption of the participants according to the Brazilian geographical regions (A), schooling (B), age (C) and gender (D). 
consumption is unsafe prevailed, especially in the North, where $30.95 \%$ of the participants believe that the consumption is unsafe, very unsafe or extremely unsafe (Figure 3B). Considering level of education, we observed that the opinion safe was higher among postgraduates $(23.39 \%)$, mainly those who have done postdoctoral studies (43.33\%) (Figure 3C) who also presented higher percentages of insect consumption and a significant association between consumption and level of education $\left[\chi^{2}(2)=24.60, p<0.0001\right]$.

\section{DISCUSSION}

Before the advance of science, the only factors explaining eating behaviour were physiological and neurochemical (HOPKINS et al.,
2016). Nowadays, other factors such as motivation, emotion, culture, religion, politics, status, learning, sensory perception, affective memories, family, gender issues, appetite, satiety and social influences also participate in the act of feeding (ALMEIDA et al., 2013). The act of eating is not a solitary event. People eat in a social environment, that causes profound influences on the choice of food, the amount of food to be consumed, the occasion of consumption and even the use of certain foods as part of the cultural identity of a people or a nation. So, cultural and/or social aspects determine what one should eat and what food taboos are. The availability of edible insects can also determine the willingness of consumers. In Brazil, few companies produce insects (NUTRINSECTA, 2019) or insect-based food such as

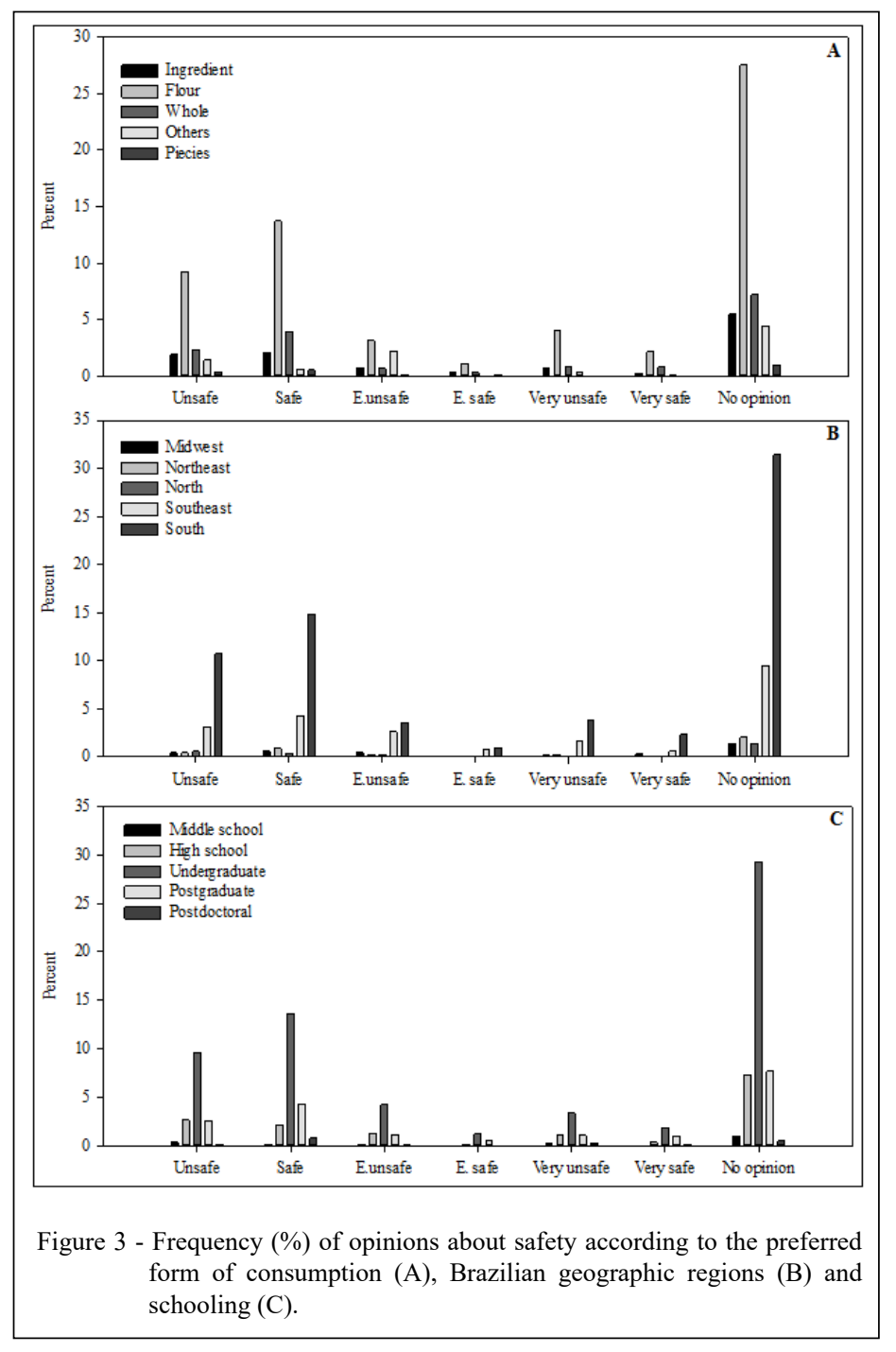

Ciência Rural, v.49, n.10, 2019. 
protein flour, protein bars and cricket protein-based cookies (HAKKUNA, 2019).

Our results suggested that gender influences the acceptance of insects in the diet, since women appear to have a greater aversion to their consumption (KELLERT, 1993). CHEUNG \& MORAES (2016) also emphasized the difference between genders in Brazil, where women associate insect consumption with the word 'disgusting', and men consider it 'unnecessary'. The lower number of participants who had attended and completed elementary or middle school corroborates the research of SCHULP \& BRUNNER (2018), where young people tend to show a lack of interest in research related to insect consumption. However, in other studies, young people have shown more intention to eat insect products (SIEGRIST et al., 2013; SOGARI et. al., 2019).

The results indicated that insect consumption occurs regardless of food habits (vegetarian, vegan, etc.), noting that participants who claim to eat everything $(86.60 \%)$ have never consumed insects. This can be caused by the disgust attributed to insects in food and to neophobia (TAN et al., 2016b; VERBEKE, 2015). Disgust is a feeling of repugnance for something, usually of an unpleasant appearance or odour. It is a basic emotion of human beings, and a kind of hygiene instinct. Feeling of disgust cannot be explained only from the biological point of view; there is also a sociocultural component, acquired over time, and transmitted from generation to generation (LA BARBERA et al., 2018). Frequently, people are more accepting of certain foods that are part of the local food tradition or of their cultural routine (CICATIELLO et al., 2016). In this sense, social pressure, desire to appear sophisticated, or the need for healthier and more convenient habits may be alternatives to overcoming aversions to certain foods (MILSTEIN et al., 2011).

Among the regions, we can highlight the largest number of people that consumed insects in the Northern region of the country, followed by the Southeast region. In the Northern region, there are indications that the consumption of insects is common in indigenous tribes (PAOLETTI et al., 2000), allowing this food source to be seen with greater familiarity among the consumers of this region. The Southeastern region of Brazil, in turn, is a pioneer in the processing of products with edible insects, offering consumers items from caramelized tenebrio to exquisite dishes. The lowest percentages of insect consumption are associated with the South and Northeast regions. Cultural and social aspects can determine preferences and generate food taboos (ALMEIDA et al., 2013). In the state of Rio Grande do Sul, Southern Brazil, the traditionalist issues of cultural identity associated with the gaucho, such as cattle breeding, sun-dried meat and barbecue, naturally condition the higher consumption of beef. In this region, about $99.1 \%$ of people consume meat at least once a year, and $75.4 \%$ from one to three times a week (GOMES et al., 2017; SCHNEIDER et al., 2014).

The participants who have at some point consumed this type of food indicated the safety of consuming insects. Those who have not consumed insects mostly have no opinion about their safety. In this sense, LA BARBERA et al. (2018) reported that previous positive experiences, such as the consumption of chocolate-covered crickets, make consumers perceive insects in a rather familiar way. Preparing a product with larvae, for example, can increase the familiarity of who is preparing it, thus increasing the chances that this person will try it (TAN et. al., 2016a).

In addition to supplying nutrients necessary for the growth, development and maintenance of an organism, food also satisfies the senses of sight, taste, smell, hearing and touch. Both nutrition and pleasure complement the fundamental requirement that food should be safe (DELANEY \& MCCARTHY, 2014).

A change in the perception of insect safety in food is evidenced by the familiarity acquired after one consumes them. While insects are a form of food unfamiliar to society, they will not be accepted as substitutes for conventional sources of protein (SCHÖSLER et al., 2012). Changes in eating habits are procedural and are constructed when a person associates the change with something of intrinsic, important, esteemed or desired value (SPAHN et al., 2010). Previous experiences play a key role in the formation of patterns of food acceptance or rejection (MILLER \& ROLLNICK, 2012). Education on alternative sources of protein may increase the acceptability of edible insects. Our results suggested that participants at more advanced levels of education (postgraduate and postdoctoral levels) have already consumed insects and consider them a safe food. This can be promoted through educational campaigns (HAMERMAN, 2016), or by their gradual insertion in the market, causing more neophobes to try edible insects (LA BARBERA et al., 2018). Although our species eats everything that is edible within each culture, we eat only a small portion of what can serve as a source of nutrients (SATTER, 2007). Thus, not everything that is biologically ingestible is culturally edible.

As omnivores, we are 'destined' to food variety, but as social beings, we only eat what has 
meaning in our culture (KORITAR et al., 2014). Food is loaded with subjectivity and concepts of identity; that is, food can be attributed to certain social and cultural groups and rejected by others. Thus, 'aversion' for the food of another culture reaffirms the distance of an individual from the culture of the other (ALVARENGA et al., 2010).

In a change of nutritional behaviour, consumers use cognitive, affective and self-assessment processes for the first steps in the change. Generally speaking, in order to make progress, people need to have a growing awareness that there are more advantages to the change than disadvantages, and they need to be confident that they are able to make and sustain changes in new eating habits (SUN, 2008).

Most participants prefer to consume insects in the form of flour, followed by as ingredients of cakes and pies. In line with our results, HARTMANN et al. (2015) also pointed out that consumers with no previous experience of insect consumption tend to consume them in processed forms. Those who have already consumed them also highlighted the consumption of whole insects. Regionally, there is also preference for the form of flour, as also observed in studies in the Netherlands (SCHÖSLER et al., 2012), Switzerland (SCHLUP \& BRUNNER, 2018), United States and India (RUBY, 2015).

In many countries, insects are consumed in their original (whole) form and processed (form of pastes or powders). Components such as proteins, fat and chitin can be isolated from insect matrices and consumed separately, and this is a way to increase acceptability among more cautious consumers. Grinding is also an alternative to increase palatability and obtain high-protein insect flours and other valuable components such as vitamins and minerals (YI et al., 2013).

In processed forms, insects become invisible, which reduces the aversion or disgust associated with consumption of the whole insect (YEOMANS et al., 2008). Although most participants, both men and women, preferred to eat insects in the form of flour, it was observed that the whole form or pieces were preferred by the men. Preference for whole insects can be justified by their familiarity with the consumption of complete and recognizable forms (TAN et al., 2015).

Contrary to Western regions, where one in every five people who consume meat would accept including insects in their diet (VERBEKE, 2015), in Brazil, almost $50 \%$ of people do not have an opinion about it, while another $27.56 \%$ believe that consuming insects is unsafe, very unsafe or extremely unsafe. When asked 'Why consume insects?' in the Southern region, 95 responses were associated with aversion to eating insects, including: 'I have no desire to consume insects. I'm disgusted. It is not something safe' and 'I do not consider including this type of animal in my diet. If there is a range of foods containing this kind of ingredient I hope it is properly identified so that I can avoid consumption'.

Conversely, 279 participants from the South region associated insect nutritional quality and sustainable consumption with their responses, such as 'They are sources of protein and require less physical space, besides reducing the environmental impact' and 'Greater nutrition with less food'. However, the acceptability of edible insects was also highlighted: 'It would be a cheaper source of protein. But it would not be in any case my first choice'. In the Southeast region, of the 200 responses obtained, 98 were associated with the nutritional value of insects, and 38 with the fact that insects are an alternative to meet the food need or the demand of population growth.

Food does not just mean positive things; it can also generate negative memories and feelings. Currently, the concepts of classical nutrition are not adequate or sufficient to make a difference in some situations. Eating attitude shows that consumer actions depend on feelings and cognition and also influence them, and that behaviour change must take into account the beliefs consumers have about food (ALMEIDA et al., 2013; JALLINOJA et al., 2010).

Although consumers are demonstrating a progressive change in behaviour and are more informed and more aware of their role in health care and acquisition of innovative products, there are still barriers that can influence them not to consume new products. To be consumed, food must break down important barriers of attitudes and behaviours of individuals, such as the body barrier and the symbolic aspects, proper to the eating act (GOULART \& LUCCHESE-CHEUNG, 2014).

Finally, there are some limitations in our study, mainly the comprehensiveness of survey. Most of the participants were from the South and Southeast regions, where the authors have contacts who helped with the distribution. In addition, the sampling was nonprobabilistic, since people who could have less food neophobia, would tend to answer the questionnaire, which makes it difficult to generalize our results and interpret/apply them to the different Brazilian regions. Another important limitation is the lack of studies about edible insects in Brazil, with the exception of GOULART \& LUCCHESE-CHEUNG (2014). We might attribute this fact to the low availability of edible insects in the Brazilian market and the lack of 
specific legislation to produce insect-based food. We emphasized that research methodologies with sensory analysis of edible insects should be boosted in order to make them more familiar to consumers.

\section{CONCLUSION}

Results of this study showed the lack of familiarity and neophobia of Brazilians regarding edible insects in their diet. Few participants consumed insects at some point; these were mostly men, showing a greater aversion than Brazilian women to the consumption of insects. As for the safety of consuming insects, we reported it is directly proportional to educational level. The information obtained contributes to the knowledge of the profile of Brazilian consumers and suggested that the consumption of edible insects can be promoted through educational strategies of approximation and demystification. Reducing the perception of edible insects in food, using forms such as flour, is a promising alternative to increase acceptance and introduce insect-based foods into the diet of Brazilians.

\section{ACKNOWLEDGEMENTS}

The authors thank the Conselho Nacional de Desenvolvimento Científico e Tecnológico (CNPq) and Coordenação de Aperfeiçoamento de Pessoal de Nível Superior, Brasil (CAPES), Finance Code 001, for providing scholarships and financial support for this work.

\section{DECLARATION OF CONFLICT OF INTERESTS}

The authors declare no conflict of interest. The founding sponsors had no role in the design of the study; in the collection, analyses, or interpretation of data; in the writing of the manuscript, and in the decision to publish the results.

\section{AUTHORS' CONTRIBUTIONS}

All authors contributed equally for the conception and writing of the manuscript. All authors critically revised the manuscript and approved of the final version.

\section{ETHICS COMMITTEE}

This study was approved by the Research Ethics Committee of Universidade Federal de Santa Maria (number 86727018.4.0000.5346)

\section{REFERENCES}

ALMEIDA S.S. et al. Psicobiologia do comportamento alimentar. Rio de Janeiro: Rubio, 2013. 227p.
ALVARENGA, M. S. et al. Development and Validity of the Disordered Eating Attitude Scale (Deas). Perceptual and Motor Skills, v.110, n.2, p.379-395, 2010. Available from: $<$ http://journals.sagepub.com/doi/10.2466/pms.110.2.379-395>. Accessed: Jul. 25, 2018. doi: 10.2466/pms.110.2.379-395.

ABPA (ASSOCIAÇ̃̃O BRASILEIRA DE PROTEÍNA ANIMAL). Available from: <http://abpa-br.com.br/>. Accessed: Aug. 03, 2019.

BEHRENS, J. H.; SILVA M. A. A. P. Atitude do consumidor em relação à soja e produtos derivados. Food Science and Technology, v.24, n.3, p.431-439, 2004. Available from: $<$ https:// dx.doi.org/10.1590/S0101-20612004000300023>. Accessed: Aug. 03, 2019.

BLÁSQUEZ, J. R. et al. Could grasshoppers be a nutritive meal? Food and Nutrition Sciences, v.3, n.2, p.164175, 2012. Available from: <https://file.scirp.org/pdf/ FNS20120200005_20348364.pdf>. Accessed: Jul. 25, 2018. doi: $10.4236 /$ fns. 2012.32025 .

BRASIL. Resolução no 466, de 12 de dezembro de 2012. BRASIL. Diário Oficial da União, 12 dez. 2012. Available from: <http://bvsms.saude.gov.br/bvs/saudelegis/cns/2013/ res0466 12 12 2012.html>. Accessed: Feb. 06, 2019.

CHEUNG, T. L.; MORAES, M. S. Inovação no setor de alimentos: insetos para consumo humano. Interações, Campo Grande, MS, v.17, n.3, p.503-515, jul./set. 2016. Available from: <http:// www.scielo.br/pdf/inter/v17n3/1518-7012-inter-17-03-0503. pdf>. Accessed: Jul. 26, 2018. doi: 10.20435/1984-042X-2016v.17-n.3(12).

CHOO, J. et al. The Importance of Traditional Ecological Knowledge for Palm-weevil Cultivation in the Venezuelan Amazon. Journal of Ethnobiology, v.29, n.1, p.113-128, 2009. Available from: <http://www.bioone.org/doi/abs/10.2993/02780771-29.1.113 >. Accessed: Jul. 27, 2018. doi: 10.2993/02780771-29.1.113

CICATIELlO, C. et al. Consumer approach to insects as food: barriers and potential for consumption in Italy. British Food Journal, v.118, n.9, p.2271-2286, 2016. Available from: <https://www.emerald.com/insight/content/doi/10.1108/ BFJ-01-2016-0015/full/html >. Accessed: Aug. 03, 2019. doi: 10.1108/BFJ-01-2016-0015.

DE FOLIART, G. R. The human use of insects as a food resource: A bibliographic account in progress. 2002. Available from: $<$ http:// labs.russell.wisc.edu/insectsasfood/the-human-use-of-insects-asa-food-resource/>. Accessed: Mar. 18, 2019.

DELANEY, M.; MCCARTHY, M. B. Saints, sinners and nonbelievers: the moral space of food. A qualitative exploration of beliefs and perspectives on healthy eating of Irish adults aged 50 70. Appetite, v.73, n.1, p.105-113, 2014. Available from: $<$ https:// www.sciencedirect.com/science/article/pii/S0195666313004388>. Accessed: Jul. 27, 2018. doi: 10.1016/j.appet.2013.10.017.

FAO. (FOOD AND AGRICULTURE ORGANIZATION OF THE UNITED NATIONS). Edible Insects: Future prospects for food and feed security. FAO forestry paper. Rome. 2013. 201p.

FISCHLER, C. El (h)omnívoro. Barcelona: Editorial Anagrama, 1995. 211p. 
FISCHLER, C. Gastro-nomy and gastro-anomy. The wisdom of the body and the biocultural crisis of modern eating [Gastronomia y gastr-anomia. Sabiduría del cuerpo y crisis biocultural de la alimentación moderna]. Gazeta de Antropología, v.26, n.1, p. art9, 2010. Available from: <https://www.researchgate.net/profile/ Claude_Fischler/publication/48296103_Gastro-nomia_y_gastroanomia Sabiduria del cuerpo y crisis biocultural de la alimentacion_moderna/links/0f317532c972 $\overline{\mathrm{fc}} 167 \mathrm{~d} 000000 /$ Gastronomia-y-gastro-anomia-Sabiduria-del-cuerpo-y-crisis-bioculturalde-la-alimentacion-moderna.pdf $>$. Accessed: Jul. 22, 2018.

GAHUKAR, R. T. Edible Insects Farming: Efficiency and Impact on Family Livelihood, Food Security, and Environment Compared With Livestock and Crops. In: DOSSEY, A. T. et al. (Eds). Insects as Sustainable Food Ingredients. Academic Press, 2016. Chap. 4. p.85-111. Available from: <https://www. sciencedirect.com/science/article/pii/B9780128028568000041?v ia\%3Dihub>. Accessed: Jul. 25, 2018. doi: 10.1016/B978-0-12802856-8.00004-1

GOMES, R. C. et al. Evolução e Qualidade da Pecuária Brasileira. Embrapa Gado de Corte, 2017. 4p. Available from: <https://www.embrapa.br/documents/10180/21470602/ EvolucaoeQualidadePecuaria.pdf/64e8985a-5c7c-b83e-ba2d168ffaa762ad $>$. Accessed: Jul. 25, 2018.

GÓMEZ-LUCIANO, C. A. et al. Consumers' willingness to purchase three alternatives to meat proteins in the United Kingdom, Spain, Brazil and the Dominican Republic. Food Quality and Preference, v.78, p.103732, 2019. Available from: <https://www.sciencedirect. com/science/article/pii/S0950329318309996?via\%3Dihub>. Accessed: Aug. 03, 2019. doi: 10.1016/j.foodqual.2019.103732.

GOULART, G. da S.; LUCCHESE-CHEUNG, T. Alimentos inovadores: comportamentos neofóbicos e desafios para as indústrias do setor. Gestão \& Produção, 2014. v.21, n.3, p.491-502. Available from: <http://www.scielo.br/scielo. php? script $=$ sci_arttext\&pid=S0104-530X2014000300004\&1 ng $=$ pt\&tlng $=$ pt $>$. Accessed: Jul. 28, 2018. doi: 10.1590/0104$530 \times 1269$.

HAKKUNA. Hakkuna proteico e nutritivo. Available from: $<$ http://hakkuna.com/>. Accessed: Feb. 15, 2019.

HAMERMAN, E. J. Cooking and disgust sensitivity influence preference for attending insect-based food events. Appetite, v.96, n.1, p.319-326, 2016. Available from: <https://www.ncbi.nlm.nih. gov/pubmed/26431679>. Accessed: Mar. 18, 2019. doi: 10.1016/j. appet.2015.09.029.

HARTMANN, C. et al. The psychology of eating insects: A crosscultural comparison between Germany and China. Food Quality and Preference, v.44, p.148-156, 2015. Available from: <https:// www.sciencedirect.com/science/article/pii/S0950329315001044> Accessed: Mar. 18, 2019. doi: 10.1016/j.foodqual.2015.04.013.

HOPKINS, M. et al. The regulation of food intake in humans. In: DE GROOT, L. J. et al. (Eds). Endotext. MDText.com, Inc: South Dartmouth (MA), 2016. Available from: <https://www.ncbi.nlm. nih.gov/books/NBK278931/>. Accessed: Aug. 03, 2019.

HOUSE, J. Consumer acceptance of insect-based foods in the Netherlands: Academic and commercial implications. Appetite, v.107, n.1, p.47-58, 2016. Available from: <https://www. sciencedirect.com/science/article/pii/S0195666316302902>. Accessed: Mar. 18, 2019. doi: 10.1016/j.foodqual.2015.11.00.
IBGE (INSTITUTO BRASILEIRO DE GEOGRAFIA E ESTATÍSTICA). Brasil em Síntese: Distribuição das pessoas de 25 anos ou mais de idade, por sexo, segundo os grupos de anos de estudo - Brasil - 2015. 2015. Available from: <https:// brasilemsintese.ibge.gov.br/educacao/anos-de-estudo-e-sexo. html >. Accessed: Feb. 08, 2019.

IBGE (INSTITUTO BRASILEIRO DE GEOGRAFIA E ESTATÍSTICA). Censo Demográfico 2010. 2010. Available from: <https://sidra.ibge.gov.br/pesquisa/censo-demografico/ demografico-2010/inicial>. Accessed: Feb. 08, 2019.

IBGE (INSTITUTO BRASILEIRO DE GEOGRAFIA E ESTATÍSTICA). População do Brasil. 2019. Available from: $<$ https://www.ibge.gov.br/apps/populacao/projecao//index.html>. Accessed: Feb. 08, 2018.

JALLINOJA, P. et al. Negotiated pleasures in health-seeking lifestyles of participants of a health promoting intervention. Health, v.14, n.2, p.115-130, 2010. Available from: <https://www. ncbi.nlm.nih.gov/pubmed/20164161>. Accessed: Mar. 18, 2019. doi: $10.1177 / 1363459309353292$.

KELLERT, S. R. Values and perceptions of invertebrates. Conservation Biology, v.7, n.4, p.845-855, 1993. doi: 10.1046/j.1523-1739.1993.740845.x.

KORITAR, P. et al. Adaptação transcultural e validação para o português da Escala de Atitudes em Relação ao Sabor da Health and Taste Attitude Scale (HTAS). Ciência \& Saúde Coletiva, v.19, n.8, p.3573-3582. 2014. Available from: <http://www.scielo. $\mathrm{br} /$ scielo.php?pid=S1413-81232014000803573\&script $=$ sci abstract\&tlng=pt $>$. Accessed: Mar. 18, 2019. doi: 10.1590/141381232014198.11692013.

LA BARBERA, F. et al. Understanding Westerners' disgust for the eating of insects: The role of food neophobia and implicit associations. Food Quality and Preference, v.64, p.120-125, 2018. Available from: <https://www.sciencedirect.com/science/ article/pii/S095032931730229X>. Accessed: Mar. 18, 2019. doi: 10.1016/j.foodqual.2017.10.002.

MANDITSERA, F. A. et al. Consumption patterns of edible insects in rural and urban areas of Zimbabwe: taste, nutritional value and availability are key elements for keeping the insect eating habit. Food Security, v.10, p.561-570, 2018. Available from: <https://link.springer.com/ article/10.1007\%2Fs12571-018-0801-8>. Accessed: Feb. 07, 2019. doi: 10.1007/s12571-018-0801-8.

MASON, J. B. et al. Fostering strategies to expand the consumption of edible insects: The value of a tripartite coalition between academia, industry, and government. Current Developments in Nutrition, v.2, n.8, p.1-5, 2018. Available from: $<$ https:// academic.oup.com/cdn/article/2/8/nzy056/5038390>. Accessed: Mar. 18, 2019. doi: 10.1093/cdn/nzy056.

MILLER W. R., ROLLNICK S. Motivational interviewing: preparing people for change. 3 ed. New York: Guilford Press. 2012.

MILSTEIN, B. et al. Why behavioral and environmental interventions are needed to improve health at lower cost. Health Affairs, v.30, n.5, p.823-832, 2011. Available from: <https://www. ncbi.nlm.nih.gov/pubmed/21555468>. Accessed: Mar. 18, 2009. doi: $10.1377 /$ hlthaff.2010.1116. 
NOWAK, V. et al. Review of food composition data for edible insects. Food Chemistry, v.193, p.39-46, 2016. Available from: <https:// www.sciencedirect.com/science/article/pii/S0308814614016781\#!>. Accessed: Mar. 18, 2018. doi: 10.1016/j.foodchem.2014.10.114.

NUTRINSECTA. Nutrinsecta: insetos comestíveis - alimento nutritivo. Accessed: $<$ http://www.nutrinsecta.com.br/>. Accessed: Feb. 15, 2019.

PAOLETTI, M. G. et al. Edible invertebrates among Amazonian Indians: A critical review of disappearing knowledge. Environment, Development and Sustainability, v.2, n.3-4, p.195-225, 2000. Available from: <https://link.springer.com/ content/pdf/10.1023\%2FA\%3A1011461907591.pdf>. Accessed: Aug. 01, 2018. doi: 10.1023/A:1011461907591.

PIHA, S. et al. The effects of consumer knowledge on the willingness to buy insect food: An exploratory cross-regional study in Northern and Central Europe. Food Quality and Preference, v.70, p.1-10. 2018. Available from: <https://www.sciencedirect. com/science/article/pii/S0950329316302646>. Accessed: Feb. 07, 2019. doi: 10.1016/j.foodqual.2016.12.006.

ROOS, N. Insects and Human Nutrition. In: HALLORAN A. et al. (Eds). Edible Insects in Sustainable Food Systems. Springer, Cham., 2018, Chap. 5, p.83-91

RUBY, M. et al. Determinants of willingness to eat insects in the USA and India. Journal of Insects as Food and Feed, v.1, n.3, p. 215225, 2015. Available from: <https://www.wageningenacademic. com/doi/10.3920/JIFF2015.0029>. Accessed: Aug. 01, 2018. doi: $10.3920 /$ JIFF2015.0029

RUBY, M. B., ROZIN, P. Disgust, sushi consumption, and other predictors of acceptance of insects as food by Americans and Indians. Food Quality and Preference. v.74, p.155-162. 2019. Available from: <https://www.sciencedirect.com/science/ article/pii/S0950329318306451>. Accessed: Feb. 07, 2019. doi: 10.1016/j.foodqual.2019.01.013

RUMPOLD, B. A.; SCHLÜTER, O. K. Potential and challenges of insects as an innovative source for food and feed production. Innovative Food Science and Emerging Technologies, v.17, p.1-11, 2013. Available from: <https://www.sciencedirect.com/ science/article/pii/S1466856412001452>. Accessed: Mar. 18, 2019. doi: 10.1016/j.ifset.2012.11.005.

SATTER, E. Eating competence: definition and evidence for the satter eating competence model. Journal of Nutrition Education and Behavior, v.39, n.5, p.142-153, 2007. Availabe from: $<\mathrm{https} / /$ www.ncbi.nlm.nih.gov/pubmed/17826695>. Accessed: Mar. 18, 2019. doi: 10.1016/j.jneb.2007.01.006.

SCHLUP, Y.; BRUNNER, T. Prospects for insects as food in Switzerland: A tobit regression. Food Quality and Preference, v.64, p.37-46, 2018. Available from: $<$ https://www. sciencedirect.com/science/article/pii/S0950329317302495>. Accessed: Mar. 18, 2019. doi: 10.1016/j.foodqual.2017.10.010.

SCHNEIDER, B. C. et al. Consumo de carnes por adultos do sul do Brasil: um estudo de base populacional. Ciência \& Saúde Coletiva, v.19, n.8, p.3583-3592, 2014. Available from: $<$ http://www.scielo. br/pdf/csc/v19n8/1413-8123-csc-19-08-03583.pdf $>$. Accessed: Mar. 18, 2019. doi: 10.1590/1413-81232014198.11702013.

SCHÖSLER, H.et al. Can we cut out the meat of the dish? Constructing consumer-oriented pathways towards meat substitution.
Appetite, v.58, n.1, p.39-47, 2012. Available from: <https://www. sciencedirect.com/science/article/pii/S0195666311005770>. Accessed: Mar. 18, 2019. doi: 10.1016/j.appet.2011.09.009.

SIEGRIST, M. et al. Antecedents of food neophobia and its association with eating behavior and food choices. Food Quality and Preference, v.30, n.2, p.293-298, 2013. Available from: <https:/www-sciencedirect.ez47.periodicos.capes.gov.br/science/ article/pii/S0950329313001109>. Accessed: Aug. 03, 2019. doi: 10.1016/j.foodqual.2013.06.013.

SOGARI, G. et al. The food neophobia scale and young adults' intention to eat insect products. International Journal of Consumer Studies, v.43, n.1, p.68-76, 2019. Available from: $<$ https://onlinelibrary.wiley.com/doi/full/10.1111/ijcs.12485>. Accessed: Aug. 03, 2019. doi: 10.1111/ijcs.12485.

SPAHN, J. M. et al. State of the evidence regarding behavior change theories and strategies in nutrition counseling to facilitate health and food behavior change. Journal of the American Dietetic Association, v.110, n.6, p.879-891, 2010. Available from: $<$ https:/www.ncbi.nlm.nih.gov/pubmed/20497777>. Accessed: Mar. 18, 2019. doi: 10.1016/j.jada.2010.03.021.

SUN, Y. H. C. Health concern, food choice motives, and attitudes toward healthy eating: The mediating role of food choice motives. Appetite, v.51, n.1, p.42-49, 2008. Available from: <https://www. ncbi.nlm.nih.gov/pubmed/18187232>. Accessed: Mar. 18, 2019 doi: 10.1016/j.appet.2007.11.004

TAN, H. S. G. et al. Insects as food: Exploring cultural exposure and individual experience as determinants of acceptance. Food Quality and Preference, v.42, p.78-89, 2015. Available from: <https://www.sciencedirect.com/ science/article/pii/S0950329315000221>. Accessed: Mar. 18, 2019. doi: 10.1016/j.foodqual.2015.01.013.

TAN, H. S. G. et al. The influence of product preparation, familiarity and individual traits on the consumer acceptance of insects as food. Food Quality and Preference, v.52, p.222-231, 2016a. Available from: <https://www.sciencedirect.com/science/ article/pii/S0950329316300908>. Accessed: Mar. 18, 2019. doi: 10.1016/j.foodqual.2016.05.003.

TAN, H. S. G. et al. Tasty but nasty? Exploring the role of sensoryliking and food appropriateness in the willingness to eat unusual novel foods like insects. Food Quality and Preference, v.48, p.293-302, 2016b. Available from: <https://www.sciencedirect. com/science/article/pii/S0950329315300021>. Accessed: Mar. 18, 2019. doi: 10.1016/j.foodqual.2015.11.00.

VANHONACKER, F. et al. Flemish consumer attitudes towards more sustainable food choices. Appetite, v.62, p.7-16, 2013 Available from: <https://www.sciencedirect.com/science/article/pii/ S0195666312004461>. Accessed: Mar. 18, 2019. doi: 10.1016/j. appet.2012.11.003

VERBEKE, W. Profiling consumers who are ready to adopt insects as a meat substitute in a Western society. Food Quality and Preference, v.39, p.147-155, 2015. Available from: $<$ https://www.sciencedirect.com/science/article/pii/ S0950329314001554>. Accessed: Mar. 18, 2019. doi: 10.1016/j. foodqual.2014.07.008.

WOOLF E. et al. Willingness to consume insect-containing foods: a survey in the United States. Food Science and Tecnology, v.102, 
p.100-105, 2019. Available from: <https://www.sciencedirect. com/science/article/pii/S0023643818310685>. Accessed: Mar. 18, 2019. doi: 10.1016/j.lwt.2018.12.010.

YEOMANS, M. R. et al. The role of expectancy in sensory and hedonic evaluation: The case of smoked salmon ice-cream. Food Quality and Preference, v.19, n.6, p.565-573, 2008. Available from: <https://www.sciencedirect.com/science/
article/pii/S0950329308000384>. Accessed: Mar. 18, 2019. doi: 10.1016/j.foodqual.2008.02.009.

YI, L. et al. Extraction and characterisation of protein fractions from five insect species. Food Chemistry, v.141, n.4, p.33413348, 2013. Available from: <https://www.sciencedirect.com/ science/article/pii/S0308814613007218>. Accessed: Mar. 18, 2019. doi: 10.1016/j.foodchem.2013.05.115.

Ciência Rural, v.49, n.10, 2019. 